\title{
Haemophiliacs win right to sue
}

\section{London \& Washington}

IN what could prove to be a turning point in their long campaign for compensation, more than 900 haemophiliacs infected with the AIDS virus won a legal battle last week that will strengthen their argument in court against the British government over its role in importing contaminated blood products in the 1980 s.

The haemophiliacs' victory gives them access to government records that could prove essential to their case. The records, which have been kept under lock and key at the Department of Health, detail government policy on the procurement of blood products in the $1980 \mathrm{~s}$, and are likely to shed light on at least one of the chief allegations; that despite knowing about the risk of HIV contamination, the government continued to import clotting factor from the United States rather than boosting domestic supplies.

The haemophiliacs also allege that the government was slow to introduce heat treatment for domestically produced clotting factor and screen high-risk domestic donors after 1985. By then HIV had been established as the cause of AIDS and a blood test was available.

Throughout the compensation campaign, the Department of Health has maintained that its blood product records are protected from disclosure by public interest immunity, a position upheld last year by the High Court.

After the hearing, the United Kingdom's Haemophilia Society urged a rapid outof-court settlement. But with the Secretary of State for Health, Mr Kenneth Clarke, opposed to such a move, a full trial is likely. Clarke thinks that the documents will not help the haemophiliac's case.

By 1985 about 1,200 haemophiliacs in Britain had become infected with HIV, largely from contaminated clotting factors imported from the United States. Of these, 962 are seeking compensation, 210 have developed AIDS and 140 have died. So far the British government has made $e x$ gratia payments of $£ 20,000$.

Gaining access to records important to compensation claims has also proved difficult for haemophiliacs in the United States where the targets of legal action are pharmaceutical companies. Unlike government departments, the companies, which include Alpha Therapeutics, Highland Therapeutics and Armour Pharmaceuticals - all subsidiaries of international corporations - are not bound by the Freedom of Information Act.

So far, the handful of US haemophiliacs who have filed negligence suits against some of these companies have met with little success. In one notable case, a claimant in Georgia succeeded in convincing a jury, only for the jury's verdict to be reversed by a judge. A common stumbling block for US claimants has been proving that they can trace the source of their infection to any one manufacturer; every year a haemophiliac uses thousands of units of clotting factor, and these are unlikely to all come from a single company.

But a more fundamental challenge, and one facing haemophiliacs in Britain as well as the United States, is the difficulty of proving negligence when most infections occurred in the early 1980 s before the cause of AIDS was known and a blood test was available.

Some haemophiliacs, and in particular those in Japan, argue that by 1983 - the year before HIV was established to be the cause of AIDS - there was already considerable evidence pointing towards nonheat-treated products as the source of infection. But Japanese health officials contend that when the haemophiliacs called for the introduction of heat treatment at that time the source of infection was far from clear. Last year about half a dozen of the 2,000 Japanese haemophiliacs thought to be infected with HIV filed negligence suits against the government and pharmaceutical companies.

David Concar \& Diane Gershon

\section{"Think again" plea from Milton Keynes}

\section{London}

THE controversial job-cutting corporate plan instituted by the Natural History Museum last April was unanimously condemned at a research meeting last week. Speaking at the 38th Symposium of Vertebrate Palaeontology and Comparative Anatomy in Milton Keynes on 2l September, Dr Beverly Halstead of Imperial College, London, delivered a scathing attack on Sir Walter Bodmer, chairman of the museum's board of trustees. The meeting was the first opportunity for researchers to discuss the plan collectively since details were released (see Nature 344, 805; 1990).

The delegates, mostly from the United Kingdom and Europe, passed a resolution calling on the Natural History Museum to rethink the plan's provisions - in particular the intention to shed 50 research jobs.

"Reduction in the range of expertise available, together with the strategy to devolve the research of the senior scientific staff away from curatorial activity, seems to strike a double blow at the rigorous taxonomic base on which all palaeontological and biological research ultimately depends".

Henry Gee

\section{MPs count the pennies}

\section{London}

THE House of Commons Public Accounts Committee, piqued by the near bankruptcy of University College, Cardiff, three years ago, yesterday issued a report saying that the Universities Funding Council (UFC) needs to strengthen its analysis of university financial forecasts, and to take "prompt remedial action" where necessary. The report, leaked to The Guardian newspaper, caused a controversy by suggesting that several British universities, including Keele and Surrey, are facing bankruptcy. This has been strongly denied by the universities concerned and by Sir Peter SwinnertonDyer, chief executive of the UFC.

University College, Cardiff, was rescued from impending bankruptcy by a $£ 4.4$ million government loan after persistently refusing to reduce spending in response to cuts in government funding. Its principal and other senior staff resigned. The report notes similar intransigence by other universities, but the suggestion that the UFC needs to take a stronger line was rejected by Swinnerton-Dyer, who says that the UFC's powers are limited by universities' autonomy.

One university finance officer says that the alarm over the hints of bankruptcy indicates a misunderstanding of the uni- versities' financial status. Although they receive almost half of their $£ 3,700$ million yearly income through the UFC, universities are autonomous and can borrow money and incur temporary deficits.

The UFC says that a university running at a deficit for two or three years is "not a cause for concern", provided this is offset by surpluses in other years.

Swinnerton-Dyer surprised the committee in February when he admitted he could not be certain that 'another Cardiff' was not brewing elsewhere in the university system. He told the committee that 44 out of 74 institutions were predicting deficits by the end of the $1989-90$ academic year, but refused to comment publicly on individual cases.

In the subsequent private meeting of the committee, Swinnerton-Dyer said that only three universities apart from the University of London were on the UFC's 'worry list'. Their names have been removed from the committee's final report, but were identified by The Guardian as Surrey, Keele and Cardiff. Surrey and Cardiff have since said that their finances are sound. Keele has acknowledged that it has a $£ 2$ million accumulated deficit, but says that this is planned, to finance a long-term programme of expansion.

Peter Aldhous 